\title{
Inclusive Review on Common Emerging Viral Infections Affecting Quail
}

\author{
Ahmed A. H. Ali ${ }^{1}$; Ahmed Abdelaziz ${ }^{2}$; Fatma Abdallah ${ }^{{ }^{*}}$ \\ ${ }^{1}$ Department of Virology, Faculty of Veterinary Medicine, Zagazig \\ University, Egypt. ${ }^{2}$ Free Veterinarian graduated from Faculty of \\ Veterinary Medicine, Mansoura University.
}

Corresponding author*: mm.fatma@yahoo.com

\begin{abstract}
Nowadays, the quails are documented as alternative species over other poultry species. The rapid growth rate, low feed necessities, high nutritional value of meat \& eggs, and short production periods are all advantages of the quail. Quail are being held in greater numbers and varieties for food production, research, and other purposes. However, there are some challenges facing quail industry as quails are susceptible to some viral diseases that have harmfully affects as quail bronchitis, avian influenza, Newcastle disease, coronavirus infection, avian encephalomyelitis, Marek's disease, lymphoid leukosis, reticuloendotheliosis tumors, and avian pox. These viral diseases are causing significant financial losses due to poor feed conversion, decreased hatchability, and increased mortality in the quail industry, and so on. Therefore, the aim of the existing manuscript is intended to present a review about the extremely vital emergent viral infections upsetting quails all over world accompanied by information on their prevention and control.
\end{abstract}

Keywords: quail; Newcastle disease virus; avian pox virus; avian influenza virus; Adenoviruses.

\section{Introduction}

The Japanese quails which considered domestic birds since $14^{\text {th }}$ century and has been grown commercially since the $16^{\text {th }}$ century (Arya et al., 2018). Up to date, the quail industry has been broadly spread in numerous countries all over the world (Redoy et al., 2017). Since quails are easy to handle and can be raised in a limited amount of space, quail farming is becoming increasingly popular (Edris et al., 2004). Other advantages of quail include their rapid growth rate, low feed requirements, high nutritional value of meat and eggs, and short generation intervals. (Yambayamba and Chileshe, 2019). Several viral infections affecting quails are like those in chickens especially that reared under intensive production system (Paulillo, 
1989). Among these viral diseases that affect quail are quail bronchitis, avian influenza, Newcastle disease, coronavirus infection, avian encephalomyelitis, Marek's disease, lymphoid leukosis, reticuloendotheliosis tumors, and avian pox. So, the most significant viral diseases affecting quail species around the world were highlighted in this review.

\section{VIRAL DISEASES}

Newcas tle disease virus

Newcastle disease (ND) is a devastating disease that affects poultry worldwide and is caused by the Newcastle disease virus (NDV). NDV is a member of the Orthoavulavirus genus, which is part of the Avulavirinae subfamily, family Paramyxoviridae, and order Mononegavirales (Amarasinghe et al., 2019). Experimental infection of three to six-weekold Japanese quail with velogenic strain of NDV caused various mortality percentages depending on the route of inoculation (Usman et al., 2008; El Tarabili et al., 2009; Sharawi et al., 2015; Mohamed and Abdel Hafez, 2016). Mazlan et al. (2017) proved that the Japanese quail is extremely susceptible to NDV infection in an experimental setting (genotype VII). In addition to, Susta et al. (2018) reported that two-week-old Japanese quails were experimentally infected with four virulent NDV strains through the oculo-nasal route showed the mortality rate ranged from $28 \%$ to less than $10 \%$. Moreover, the virus replication was mild to moderate in contact birds and inoculated birds, respectively. Effective NDV regulation in quails requires both live and inactivated vaccines (Lima et al., 2004; Paulillo et al., 2009).

\section{Adenoviruses}

Adenoviruses induce quail bronchitis (Olsen, 1950), inclusion body hepatitis (Jack et al., 1987) and Egg Drop Syndrome-76 (Kataria et al., 1991). Quail bronchitis (QB) is a highly contagious acute upper respiratory infection caused by type I avian adenoviruses (DuBose et al., 1958). Quail bronchitis occurs primarily in captive bobwhite quail and less commonly in Japanese quail (Chew-Lin, 1980). Quail bronchitis is most serious in young quail under 21 days of age, causing $100 \%$ morbidity and $50 \%$ mortality, respectively (Jack and Reed, 1990). Inclusion Body Hepatitis (IBH), caused by avian adenovirus 1, happens in quails at 5-week-old of age (Singh et al., 1995). However, an IBH outbreak in adult Japanese quail has been reported (Grewal et al., 1994). Egg Drop Syndrome-76 
(EDS-76), caused by avian adenovirus-3, with the isolated virus in quail being serologic ally distinct from that in chickens (Dash and Pradhan, 1992). There is no treatment for adenovirus infection (Singh et al., 2016).

Lymphoprolife rative viral diseases

Lymphoprolife rative diseases have also been found to occur naturally in quail but are not common except in quail that are reared intensively (Kobayashi et al., 1986). In quails, the MD Virus (MDV) is the cause of tumor disease (Adedeji et al., 2019). MDV is aetiologically involved in the outbreaks of lymphoproliferative disease in in eight Japanese quail's flocks. (Imai et al., 1990). MD features included low MDV antibody detection and a low frequency of lymphoproliferation in the nervous system. Nerves are more often affected in quail with Marek's disease, but the incidence of lesions is less than that seen in affected chickens (Khare et al., 1975). In Japanese quails, the Avian Leukosis Virus (ALV) could cause tumors (Wight, 1963), and quails with antibodies against ALV subgroup A had lymphoproliferative disease (Schat et al., 1976). In natural infection, malignant tumor approximating reticuloendothelios is registered in quails (Carlson et al., 1974). In Japanese quail, the avian myeloblastos is virus could cause a wide range of neoplasms like those found in chickens (Moscovici and Macintyre, 1966).

\section{Avian pox virus}

Avian pox is an acute contagious viral disease caused by Avipoxvirus genus within Poxviridae family (Bolte et al., 1999). Avian pox in quail is a serious disease that may result in very high mortality especially diphtheritic form in the respiratory tract (Tripathy and Reed, 1997). Avian pox virus disease is seasonal, being most prevalent during the warmer episodes of the year when arthropods are most abundant (Shane, 1985). Avipoxvirus infection is rare in quails (Poonacha and Wilson, 1981). Pigeons and fowl Pox vaccines are thought to be effective in preventing poxvirus infection (Promkuntod et al., 2003).

\section{Avian Influe nza virus}

Avian Influenza (AI) is a zoonotic viral disease that causes high morbidity and mortality in avian species and is characterized by respiratory, gastrointestinal, and nervous manifestations (Jordan, 1996). The causative agent of the AI is influenza A virus belonging to Orthomyxoviridae family. For the first time in 1966-1968, avian influenza virus with 
respiratory symptoms and high mortality was detected in quail less than 3 months of age in Italy (Nardelli et al., 1970). Many AIV subtypes outbreaks have been revealed in quail flocks in several countries (Arya et al., 2018). Influenza viruses of various subtypes (H7N2, H5N2, H9N2, H7N3, and H10N8) have been isolated sporadically from quail in Europe, North America, and Asia (Saito et al., 1993; Suarez et al., 1999; Guo et al., 2000). Japanese quail is thought to be a reservoir for AIV strains, offering a way to develop new variant strains that can infect various poultry species by crossing species barriers (Perez et al., 2003; Wan and Perez, 2006; Wang et al., 2008). The highly pathogenic AIV H5N1 infection was found to be highly Furthermore, highly pathogenic AIV H5N1 strains isolated from geese can infect quails, with virus shedding lasting longer than in chickens (Webster et al., 2002; Saito et al., 2009). On the other hand, it was found that Japanese quails are resistant to HPAIV H5N3 (Tashiro et al., 1987). A research on quails in Egypt showed that vaccination with inactivated AI vaccines at the age of eight days resulted in appropriate titers by the third week after vaccination, with the highest titers reported at the fourth and fifth weeks after vaccination (Saad et al., 2010). Furthermore, the H5N8 strain was isolated from two wild quail samples in addition to domestic Egyptian quail (Shehata et al., 2019). In chickens and quails, AIV H9N2 outbreaks showed stable lineages (Naeem et al., 1999). The key method of avoiding avian influenza infection in quails is vaccination combined with biosecurity measures.

\section{Infectious bronchitis virus}

Infectious bronchitis virus (IBV) infection is characterized by excessive oculo-nasal secretion, as well as, a decrease in weight gain and feed competence (Grgic et al., 2008). Also, IBV disrupts kidney and reproductive tract, resulting in renal failure and decreased egg production, respectively (Cavanagh, 2007). The potential vulnerability of native domesticated quails to IBV can be tested using experimental IBV inoculation in quail.

\section{Conclusion}

It's important to pay attention to quail production because it could be used as a replacement for chicken meat or eggs. To boost production and immunity, proper management, prevention, and control of serious viral diseases affecting quails are essential. 
References

Adedeji AJ, Akanbi OB, Luka PD and Abdu P (2019): Natural outbreak of Marek's disease in indigenous chicken and Japanese quail (Coturnix coturnix japonica) in Jos, Plateau State, Nigeria. Open Veterinary Journal, 9 (2): 151-156.

Amarasinghe GK, Ayllón MA, Bào Y, Basler CF, Bavari $S$, Blasdell KR, Briese T, Brown PA, Bukreyev A, Balkema-B us chmann A, Buchholz UJ, Chabi-Jesus C, Chandran K, Chiapponi C, Crozier I, L. de Swart R, Dietzgen RG, Dolnik O, Drexler JF, Dürrwald R, Dundon WG, Duprex WP, Dye JM, Easton AJ, AR Fooks, Formenty

PBH, Fouchier RAM, FreitasAstúa J, Rubbenstroth D, Shī M, Simmonds P, Smither SK, Sozzi E, Spann K, Towner JS, Hoogen B, Vasilakis N, Wahl V, Walker PJ, Wang L, Whitfield AE, Williams JV, Zerbini FM, Zhāng T, Zhang YZ, Kuhn JH(2019): Taxonomy of the order Mononegavirales: Arch Virol. 164: 1967-1980.

Arya K, Gupta R, Saxena VL. (2018): Quail survey: Elaborative information and its prospects. Research Journal of Life Science, Bioinformatics, Pharmaceutical and Chemical Sciences, 4: 209.
Bolte AL, Meurer J and Kale ta

EF (1999): Avian host spectrum of avipoxviruses. Avian Pathology, 28: 415-432.

Carls on UC, Seawright GL and Rettit JR (1974): Reticuloendothelios is in Japanese quail. Avian Pathology,3: 169-175. Dutton RL, Kenzy SG, Becker WA: Marek's disease in the Japanese quail (Coturnix coturnix japonica). Poultry Sci 52:139143.

Cavanagh, D (2007): Coronavirus avian infectious bronchitis virus. Vet. Res. 38:281-297.

Chew-Lin M: Adult coturnix quail bronchitis (1980): Avian Dis 24:520-526.

Dash BB and Pradhan, HK (1992): Outbreaks of egg drop syndrome due to EDS-67 virus in quail (Coturnix coturnix japonica). Veterinary Record, 131: 264-265.

DuBose RT, Grumbles LC and Flowers AI (1958): The isolation of nonbacterial agent from quail with a respiratory disease. Poultry Science, 37: 654-658.

Edris AM, Shaltout FA and Arab WS (2004): Bacterial evaluation of quail meat. Benha Veterinary Medical Journal, 16 (1): 1-14.

El-Tarabili MM, El-Shahiedy MS, Hammouda MS. (2009): Natural and experimental 
infections of quails (Couturnix couturnix japonica) with

Newcastle disease virus. Suez Canal Veterinary Medical Journal, 16: 67-80.

Gre wal GS, Singh A, Singh B and Oberoi MS (1994): Inclusion body hepatitis in Japanese quail (Coturnix coturnix japonica). Indian Journal of Animal Science, 64: 665-667.

Grgic, H. D. B. Hunter, P. Hunton, and E. Nagy (2008): Pathogenicity of infectious bronchitis virus isolates from Ontario chickens. Can. J. Vet. Res. 72:403-410.

Guo YJ, Krauss S, Senne DA, Mo IP, Lo KS, Xiong XP, Norwood M, Shortridge KF, Webster RG and Guan Y (2000): Characterization of the pathogenicity of members of the newly established H9N2 influenza virus lineages in Asian Virology, 267: 279-288.

Imai K, Yuasa N, Kobayashp S, Nakamura K, Tsukamoto K. and Hihara $H$ (1990): Isolation of Marek's disease virus from Japanese quail with lymphoproliferative disease. Avian Pathology, 19: 119-129.

Jack SW and Reed WM (1990): Pathology of experimentally induced quail bronchitis. Avian Diseases, 34: 44-51.

Jack SW, Reed WM and Bryan TA (1987): Inclusion body hepatitis in Bobwhite quail
(Colinus virginianus). Avian Diseases, 31: 661-665.

Jordan FTW

(1996):

Orthomyxoviridae (Avian Influenza). In: Jordan, F.T.W and Pattison, M. (eds) Poultry Disease. 4th Edt. W.B. Saunders, London, pp: 156-165.

Kataria JM, Swain P, Dash BB and Verma KC (1991): Egg drop syndrome-76 (EDS-76) virus infection in Japanese quail. Proceedings in the Souvenir 12th Annual Conference of IAVMI.

Khare ML, Grun J, Adams E.V. (1975): Marek's Disease in Japanese Quail_a Pathological, Virological and Serological Study. poultry science, 54: 20662081.

Kobayashi S, Kobayashi K, Mikami T (1986): A study of Marek's disease in Japanese quails vaccinated with herpesvirus of turkeys. Avian Dis 30:816-819.

Lima FS, Santin E, Paulillo AC and Doretto JL (2004): Evaluation of different programs of Newcastle disease vaccination in Japanese quail (Coturnix coturnix japonica). International Journal of Poultry Science, 3: 354-356.

Mazlan LF, Bachek NF, Mahamud SNA, Idris LH, Wei TS, Omar AR, Noor MHM (2017): The positive expression of genotype VII Newcastle disease virus (Malaysian isolate) in Japanese quails (Coturnix 
coturnix japonica), Veterinary World, 10(5): 542-548.

Mohamed MA and Abdel Hafez MS (2016): The susceptibility of Japanese quails to the infection with chicken originated Newcastle disease virus. Journal of Advanced Veterinary Research, 6 (1): 3743.

Moscovici C and Macintyre EH (1966): Effect of avian myeloblastosis virus in the Japanese quail. Journal of Bacteriology, 92: 1141-1149.

Naeem K, Ullah A, Manvell RJ and Alexander DJ (1999): Avian influenza A subtype H9N2 in poultry in Pakistan. Veterinary Record, 145: 560.

Nardelli L, Rinaldi A, Pereira HG and Mandelli G (1970): Influenza virus infections in Japanese quails. Archive of Experimental Veterinary Medicine, 24: 231-249.

Olsen N.O (1950): A respiratory disease (bronchitis) of quail caused by a virus. Proceeding of 54th Annual Meeting, US Livestock, 171-147.

Paulillo AC (1989): Avaliação da resposta imune e da performance zootécnica de poedeiras vacinadas experimentalmente contra a doença de Newcastle. Tese de Livre Docência em Ornitopatologia, Faculdade de Ciências Agrárias e Veterinárias, Jaboticabal, Universidade Estadual Paulista, p.116
Paulillo AC, Schmidt EMS, Denadai J, Lima FS and Junior LD (2009): Experimental vaccination against Newcastle disease in Japanese quails (Coturnix coturnix japonica): clinical and immunological parameters. International Journal of Poultry Science, 8(1): 52-54.

PerezDR, Lim W, SeilerJP, Yi G, Peiris M, Shortridge KF and Webster RG (2003): Role of quail in the interspecies transmission of $\mathrm{H} 9$ influenza $\mathrm{A}$ viruses: molecular changes on HA that correspond to adaptation from ducks to chickens. Journal of Virology, 77: 3148-3156.

Poonacha KB and Wilson $M$ (1981): Avian pox in pen-raised Bobwhite quail. Journal of American Veterinary Medical Association, 179: 1264-1265.

Promkuntod N, Antarasena C, Prommuang $P$ and Thiptara $A$ (2003):

Experimental assessment of live virus fowl pox and pigeon pox vaccines for control of quail pox virus NK992/43 isolate. Kasetsart Veterinarians, 13 (3): 24-31.

Redoy MRA, Shuvo AAS and Al-Mamun M (2017): A review on present status, problems and prospects of quail farming in Bangladesh. Bangladesh Journal of Animal Science, 46(2): 109120.

Saad MA, Abd-Elhady AI and El-Nagar A (2010): Study on immune response of quail for 
avian influenza vaccines. Journal of the American Science, 6 (12): 1475-1478.

Saito T, Kawaoka Y, Webster RG (1993): Phylogenetic analysis of the N8 neuraminida se gene of influenza A virus. Virology. 193:868-876.

Saito T, Watanabe C, Takemae N, Chaisingh A, Uchida Y, Buranathai C, Suzuki H, Okamatsu M, Imada T, Parchariyanon S (2009): Pathogenicity of highly pathogenic avian influenza viruses of $\mathrm{H} 5 \mathrm{~N} 1$ subtype isolated in Thailand for different poultry species. Veterinary Microbiology, 133: 65-74.

Schat KA, Gonzalez J, Solonzano A, Avila $\mathbf{E}$ and Witter RL (1976): A lymphoproliferative disease in Japanese quail. Avian Diseases, 20: 153-161.

Shane SM (1985): Common diseases and other conditions of quail. Avian/Exotic Pract 2:1323. Newcastle disease virus (Malaysian isolate) in Japanese quails (Coturnix coturnix japonica), Veterinary World, 10(5): 542-548.

Sharawi S, El-Habbaa AS, Heba MZ and Khodeir MH (2015): Experimental infection of quail by NDV and its immune response to vaccination. Benha Veterinary Medical Journal, 29 (2): 218-224.

Shehata AA, Sedeik ME, Elbestawy AR, Zain El-
Abideen MA, Ibrahim HH, Kilany WH and Ali A (2019): Co-infections, genetic, and antigenic relatedness of avian influenza $\mathrm{H} 5 \mathrm{~N} 8$ and $\mathrm{H} 5 \mathrm{~N} 1$ viruses in domestic and wild birds in Egypt. Poultry Science, 98 (6): 2371-2379.

Singh A, Bekele AZ, Patnayak DP, Jindal N, Porter RE, Mor SK and Goyal SM (2016): Molecular characterization of quail bronchitis virus isolated from Bobwhite quail in Minnesota. Poultry Science, 95: 2815-2818.

Singh B, Oberoi MS, Singh A (1995): Pathogenicity of quail's inclusion body hepatitis virus (avian adenovirus 1) for Japanese quails and broiler chicks. Veterinary research Communication, 19(6):545-551.

Suarez DL, Garci M, Latimer J, Senne D, PerdueM (1999): Phylogenetic analysis of $\mathrm{H} 7$ avian influenza viruses isolated from the live bird markets of the Northeast United States. J. Virology ,73:3567-3573.

Susta L, SegoviaD, Olivier TL, Dimitrov KM, Shittu I, Marcano $V$ and Miller PJ (2018): Newcastle disease virus infection in quail. Veterinary Pathology, 55 (5): 682-692.

Tashiro M, Reinacher $M$ and Rott R (1987): Aggravation of pathogenicity of an avian influenza virus by adaptation to quails. Archive of Virology, 93: 81-95. 
Tripathy, D.N. \& Reed, W.M. (1997). Pox. In B.W. Calnek, H.J.Barnes, C.W. Beard, R.L. Mc Dougald \& Y.M. Saif (Eds.), Diseases of Poultry 10th edition (pp. 643-659). Ames, IA: Iowa State University Press.

Usman BA, Mani AU, ElYuguda AD and Diarra SS (2008): The Effect of supplemental ascorbic acid on the development of Newcastle disease in Japanese quail (Coturnix coturnix Japonica) exposed to high ambient temperature. International Journal of Poultry Science, 7 (4): 328-332.

Wan $H$ and Perez DR (2006): Quail carry sialic acid receptors compatible with binding of avian and human influenza viruses. Virology, 346: 278-286.

Wang G, Zhan D, Li L, Lei F, Liu B, Liu D, Xiao H, Feng Y, Li J, Yang B (2008): H5N1 avian influenza re-emergence of Lake Qinghai: phylogenetic and antigenic analyses of the newly isolated viruses and roles of migratory birds in virus circulation. Journal of Genetic Virology, 89: 697-702.

Webster RG, Guan Y, Peiris M, Walker D, Krauss S, Zhou NN, Govorkova EA, Ellis TM, Dyrting KC, Sit $T$ (2002): Characterization of H5N1 influenza viruses that continue to circulate in geese in Southeastern China. Journal of Virology, 76:118-126.

Wight PAL (1963): Lymphoid leucosis and fowl paralysis in the quail. Vet Rec ,75:685-687.

Yambayamba KES and Chileshe PC (2019): Effect of increased photoperiod on feed intake, egg production and Egg size in Japanese quail (Coturnix japonica) under Zambian conditions. EC Veterinary Science. 45: 334-342.

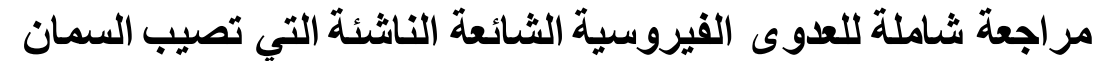

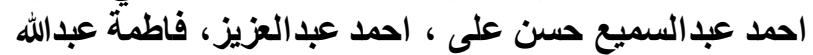

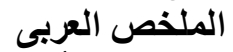

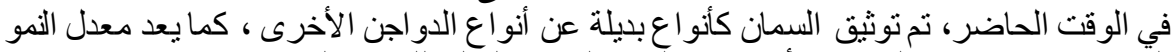

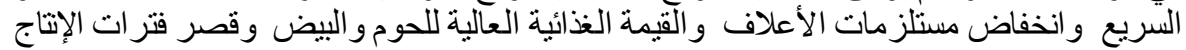

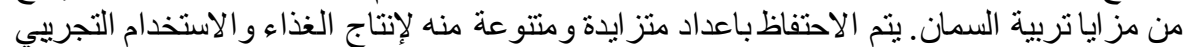

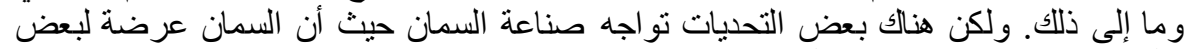

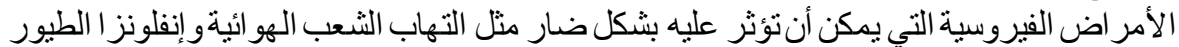

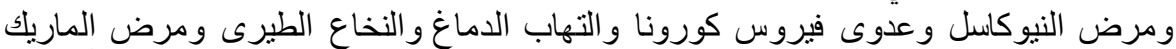

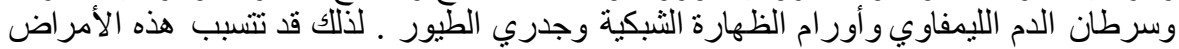

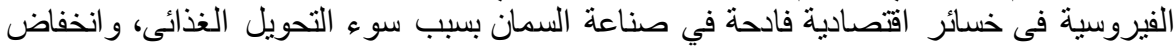

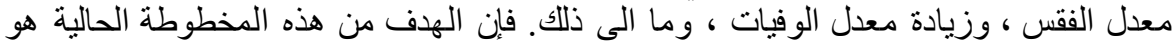

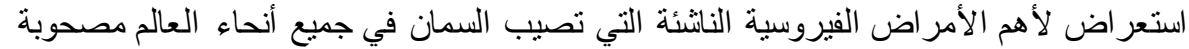
بمعلومات عن الوقاية والسبطرة. 